\title{
Analysis of the surface roughness and microhardness of dental restorative materials exposed to heat sources and cold temperatures for human identification purposes
}

Roberto Cesar Biancalana', Sergio Augusto de Freitas Vincenti ${ }^{2}$, Ricardo Henrique Alves da Silva ${ }^{1}$ and Fernanda Carvalho Panzeri Pires-de-Souza ${ }^{2^{*}}$ (D)

\begin{abstract}
Background: Fatal accidents involving the action of heat, such as burns, explosions, automobile accidents, and aircraft crashes, among others, or action of cold, such as collisions in snowy locations, severe blizzards, cold waves, earthquakes, and avalanches, are frequent day-to-day occurrences. During post-mortem dental examination of victims, restorative materials such as the composite resin (CR), glass ionomer cement $(\mathrm{G} \mid \mathrm{C})$, and amalgam may be found. The action of the heat or cold on these materials may change their properties. This study aimed to evaluate the changes occurred in the surface roughness and Knoop microhardness of the dental restorative materials of freezing or burnt victims, supporting an adequate comparison with the antemortem data, helping on human identification process.
\end{abstract}

Methods: One hundred eighty caries-free bovine teeth were prepared and separated into groups, according to the restorative material, temperature, and period for analysis. The surface roughness and microhardness were analyzed by a profilometer and a microhardness tester, before and after the action of the heat $\left(100^{\circ} \mathrm{C}, 200^{\circ} \mathrm{C}, 300^{\circ} \mathrm{C}\right)$ and the cold temperatures $\left(2.5^{\circ} \mathrm{C},-20^{\circ} \mathrm{C},-80^{\circ} \mathrm{C}\right)$.

Results: The results demonstrated that there was no alteration on properties of $\mathrm{CR}$ after the heat that caused significant changes in the surface roughness of GIC and amalgam and the microhardness of GIC. The low temperatures produced no significant differences in any of the properties of the restorative materials studied.

Conclusion: The surface roughness and Knoop microhardness tests could distinguish the tooth-colored restorative materials irrespective of the action of the heat or cold temperatures.

Keywords: Forensic sciences, Forensic odontology, Dental materials, Heat source, Cold temperature, Surface roughness, Microhardness

\footnotetext{
* Correspondence: ferpanzeri@usp.br

2Department of Dental Materials and Prosthodontics, Ribeirao Preto School

of Dentistry, University of Sao Paulo, Av. do Café, s/n 14040-904, Ribeirao

Preto, Sao Paulo, Brazil

Full list of author information is available at the end of the article
} 


\section{Background}

There are situations such as air crashes or car accidents with explosions and fires that can result in carbonized remnants of fatal burn victims (Skinner and Sterenberg 2005). The intense direct or indirect heat is capable of generating significant damage of the facial soft tissues (Fereira et al. 2008), and a high degree of carbonization of the bodies may result in difficulties with human identification (Skinner and Sterenberg 2005).

Other types of accidents, such as landslides, heavy snowstorms, collisions, or snow avalanches, in which death occurs as a result of low temperatures or from severe traumas and polytraumas (Boyd et al. 2009), may also make it difficult to identify the corpses adequately. In these accidents, it can be difficult to access victims due to the climatic and geographic conditions of the site, and a longer time to locate the bodies may be required (Blau and Briggs 2011). In this way, there is a high probability of finding the corpses in an advanced stage of decomposition (Michaud and Foran 2011).

In these situations, forensic odontology may be an appropriate and feasible solution for human identification, decreasing the working time and material costs, in addition to being highly reliable, provided that careful, meticulous, and organized work is done (Valenzuela et al. 2000).

The human identification through examining the dental arches is feasible because dental tissues are resistant to the exposure to extreme temperatures (Hill et al. 2011). The teeth are frequently the only findings that can be analyzed after the action of heat or cold, since both the teeth and restorative materials used for performing dental treatments, such as the composite resin (CR), glass ionomer cement (GIC) (Della Bona et al. 2009), or silver amalgam (Upadhyay et al. 2006), are highly resistant to the action of damaging agents (Bush et al. 2006).

Changes in the physical and mechanical properties such as color (Biancalana et al. 2017a, b; Biancalana et al. 2017a, b), surface roughness, and microhardness, when these materials have been exposed to high or low temperatures, may help with the distinction between the tooth-colored restorative materials (CR and GIC) and facilitate comparison between the antemortem and post-mortem dental data of the victims, thereby contributing to the outcome of a positive identification or exclusion of a suspected individual. The analysis of these materials may also collaborate with the investigations by offering information relative to the approximate temperature to which the bodies were subjected and the period during which they were exposed to these conditions.

Considering the scarcity of literature that correlates the properties of dental restorative materials to the forensic field, this study aimed to evaluate the effect of the heat and cold on the surface roughness and Knoop microhardness of CR, GIC, and amalgam by simulating the behavior of these materials when they are present in the teeth of victims of these types of events, with the purpose of contributing to forensic odontology in the process of human identification.

\section{Methods}

One hundred eighty caries-free bovine incisive teeth were prepared $(6 \times 6 \times 2 \mathrm{~mm})$ in the central region of the buccal surface and randomly separated into three groups, according to the restorative material used (Table 1).

After teeth restoration, initial readouts of surface roughness (profilometer Mitutoyo ${ }^{\circledR}$ Surftest SJ-201P, Kanagawa, Japan) and Knoop microhardness (Shimadzu Micro Hardness tester ${ }^{\bullet}$ HMV-2, Tokyo, Japan) were performed.

The roughness of the restorations, determined by irregularities and ledges (peaks, valleys, and waves) at the surface of the restorative materials were read in a single direction, in a length of $2.4 \mathrm{~mm}$, being three cut-off points of $0.8 \mathrm{~mm}$, at a speed of $0.5 \mathrm{~mm} / \mathrm{s}$. Three readouts were taken for each filling: a central readout at $3 \mathrm{~mm}$ from the cavity margins; another two at $1 \mathrm{~mm}$ to the left; and $1 \mathrm{~mm}$ to the right of the first one (Leitão and Hegdahl 1981). The mean value of the three readouts was considered as the initial readout of the surface roughness, denominated initial $\mathrm{Ra}$ (roughness average) value.

For the microhardness analysis, a penetrator with a pyramid-shaped tip and rectangular base was applied on the restorative material, in a perpendicular direction, under a static vertical load of $25 \mathrm{~g}$ for $5 \mathrm{~s}$, generating an inverted pyramid-shaped geometrical figure. The microhardness of the material was determined by measuring the most extensive diagonal line of the diamond shape mark imprinted on it by the penetrator, the value of which was applied in a mathematical formula to obtain the results:

$$
\mathrm{KHN}=\frac{1,451 F}{d^{2}}
$$

Being $\mathrm{KHN}=$ Knoop hardness number; $F=$ force applied, which was $25 \mathrm{~g}$; and $d=$ the most extensive diagonal length of the indentation. Three penetrations were performed, in different positions, on the restorative material: a central one, and another two at $1 \mathrm{~mm}$ to the left, and $1 \mathrm{~mm}$ to the right of the first mark. The mean value of the readout of these three penetrations was considered as the initial microhardness value, for each tooth.

The teeth restored with each material were randomly separated into groups $(n=10)$ according to the temperature to which they were exposed. For the cold tests, $2.5^{\circ} \mathrm{C}$ (frost free refrigerator, RFGE $700 \mathrm{GE}^{\oplus}$, Campinas, SP, Brazil), $-20^{\circ} \mathrm{C}$ (vertical freezer, CVU18 
Table 1 Used material, commercial brands, manufacturers, and restorative method

\begin{tabular}{|c|c|c|c|}
\hline Category & $\begin{array}{l}\text { Commercial } \\
\text { name }\end{array}$ & Manufacturer & $\begin{array}{l}\text { Restorative method } \\
\text { (clinical steps) }\end{array}$ \\
\hline $\begin{array}{l}\text { Composite } \\
\text { resin }\end{array}$ & $\begin{array}{l}\text { Filtek }^{\text {TM }} Z 250 \\
\text { XT }\end{array}$ & $\begin{array}{l}\text { 3M ESPE' } \\
\text { SP, Brazil Sumare, }\end{array}$ & 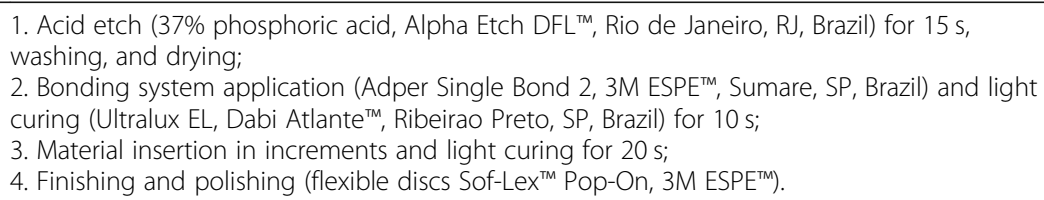 \\
\hline $\begin{array}{l}\text { Glass ionomer } \\
\text { cement }\end{array}$ & Ketac $^{\mathrm{TM}}$ Fil Plus & $\begin{array}{l}\text { 3M ESPE'T , Sumare, } \\
\text { SP, Brazil }\end{array}$ & $\begin{array}{l}\text { 1. Powder/liquid (1:1) agglutination up to } 1 \mathrm{~min} \text {; } \\
\text { 2. Material application in increments until the cavity filling. }\end{array}$ \\
\hline Amalgam & $\begin{array}{l}\text { Amalgam gs- } \\
80 \text { (2 Spill) }\end{array}$ & $\begin{array}{l}\text { SDI' }{ }^{\mathrm{TM}}, \text { Bayswater, } \\
\text { Victoria, Austrália }\end{array}$ & $\begin{array}{l}\text { 1. Trituration (Ultramat 2, Dabi Atlante }{ }^{T M} \text { ) for } 8 \mathrm{~s} \text {. } \\
\text { 2. Condensation, until the cavity filling, burnish, and finishing (carbide drill FG 7901F, KG } \\
\text { Sorensen }{ }^{T M} \text {, Cotia, SP, Brazil). } \\
\text { 3. Polishing after } 48 \text { h (Kit Viking } 8089, \mathrm{KG} \text { Sorensen }{ }^{T M} \text { ) }\end{array}$ \\
\hline
\end{tabular}

Consul ${ }^{\circ}$, Joinville, SC, Brazil), or $-80^{\circ} \mathrm{C}$ (Ultra Freezer, AL 374-80 V, American Lab ${ }^{\circ}$, Charqueada, SP, Brazil). For the heat tests, $100^{\circ} \mathrm{C}, 200^{\circ} \mathrm{C}$, or $300^{\circ} \mathrm{C}$ (vacuum furnace, Alumini-Sinter Press, $\mathrm{EDG}^{\circ}$, Sao Carlos, SP, Brazil).

After the action of the cold (for 7 and 30 days) and heat (for $15 \mathrm{~min}$ ), at the different temperatures, all the teeth were analyzed again, following the methodology previously described, concerning the surface roughness and microhardness.

The variations in the surface roughness $(\Delta \mathrm{Ra})$ were calculated by the following formula:

$$
\Delta \mathrm{Ra}=\mathrm{Ra}_{F}-\mathrm{Ra}_{i}
$$

In it, $\mathrm{Ra}_{i}$ is referred to as the initial measurement and $\mathrm{Ra}_{F}$ as the final surface roughness measurement. The changes in the microhardness $(\Delta \mathrm{KHN})$ were calculated using the following formula:

$$
\Delta \mathrm{KHN}=\mathrm{KHN}_{F}-\mathrm{KHN}_{i}
$$

In this formula, $\mathrm{KHN}_{i}$ is referred to as the initial measurement and $\mathrm{KHN}_{F}$ as the final microhardness measurement. The $\Delta \mathrm{Ra}$ and $\Delta \mathrm{KHN}$ values of the groups exposed to the high temperatures were statistically analyzed by one-way ANOVA, Tukey test, $p<0.5$; for the low temperatures, the data were analyzed by two-way ANOVA, Bonferroni test, $p<0.5$.

\section{Results}

Comparisons of the $\Delta \mathrm{Ra}$ mean values of the materials after exposure to the cold and heat may be visualized in Figs. 1 and 2, respectively. None of the comparisons between the materials and temperatures, in the cold, resulted in a significant difference $(p>.05)$.

The results obtained from the CR fillings after exposure to the heat demonstrated that there was no significant difference $(p>.05)$ in $\Delta \mathrm{Ra}$ between the three temperatures tested. Relative to $\mathrm{GIC}$, the group exposed to $300^{\circ} \mathrm{C}$ presented significant difference $(p<.05)$ in comparison with the group exposed to $100{ }^{\circ} \mathrm{C}$ so that the higher the temperature to which the tooth was subjected, the higher was the surface roughness values found. Those two mentioned above presented no difference $(p>.05)$ in comparison with the group exposed to $200^{\circ} \mathrm{C}$. For the amalgam, the most significant change in the surface roughness occurred after the exposure to $300^{\circ} \mathrm{C}$, showing statistically different results $(p<.05)$ when compared with the groups exposed to lower temperatures, which presented no difference $(p>.05)$ between them.

When comparing the different materials, higher $\Delta \mathrm{Ra}$ was verified for GIC in comparison with CR, with significant difference $(p<.05)$ for all the groups at all the temperatures, similar to amalgam only at the temperature of $300^{\circ} \mathrm{C}$. This one showed difference $(p<.05)$ in comparison with $\mathrm{CR}$ when exposed to 100 and $200^{\circ} \mathrm{C}$.

Comparisons of the mean of the $\Delta \mathrm{KHN}$ values of the materials after exposure to cold and heat may be visualized in Figs. 3 and 4, respectively. The results obtained for the cold temperatures demonstrated that no significant change $(p>.05)$ in $\Delta \mathrm{KHN}$ occurred after 7 and 30 days, irrespective of the temperature.

In the heat action, there was no significant difference $(p>.05)$ in $\triangle \mathrm{KHN}$ when the CR was exposed to the different temperatures. As regards GIC, the higher temperatures caused the most statistically significant changes in the microhardness $(p<.05)$. There were no statistically significant differences $(p>.05)$ between the temperatures to which the amalgam samples were subjected.

Comparing the results between the materials, the authors verified that GIC presented higher $\Delta \mathrm{KHN}(p<.05)$ than the other materials after exposure to $200^{\circ} \mathrm{C}$, and this difference remained $(p<.05)$ at $300^{\circ} \mathrm{C}$. After $100^{\circ} \mathrm{C}$, the changes in the GIC microhardness were similar $(p>.05)$ to that of the other materials at the same temperature. For all the other comparisons between the different temperatures, there were statistically significant differences $(p<.05)$.

\section{Discussion}

This study aimed to evaluate the action of cold and heat on the surface roughness and Knoop microhardness of 


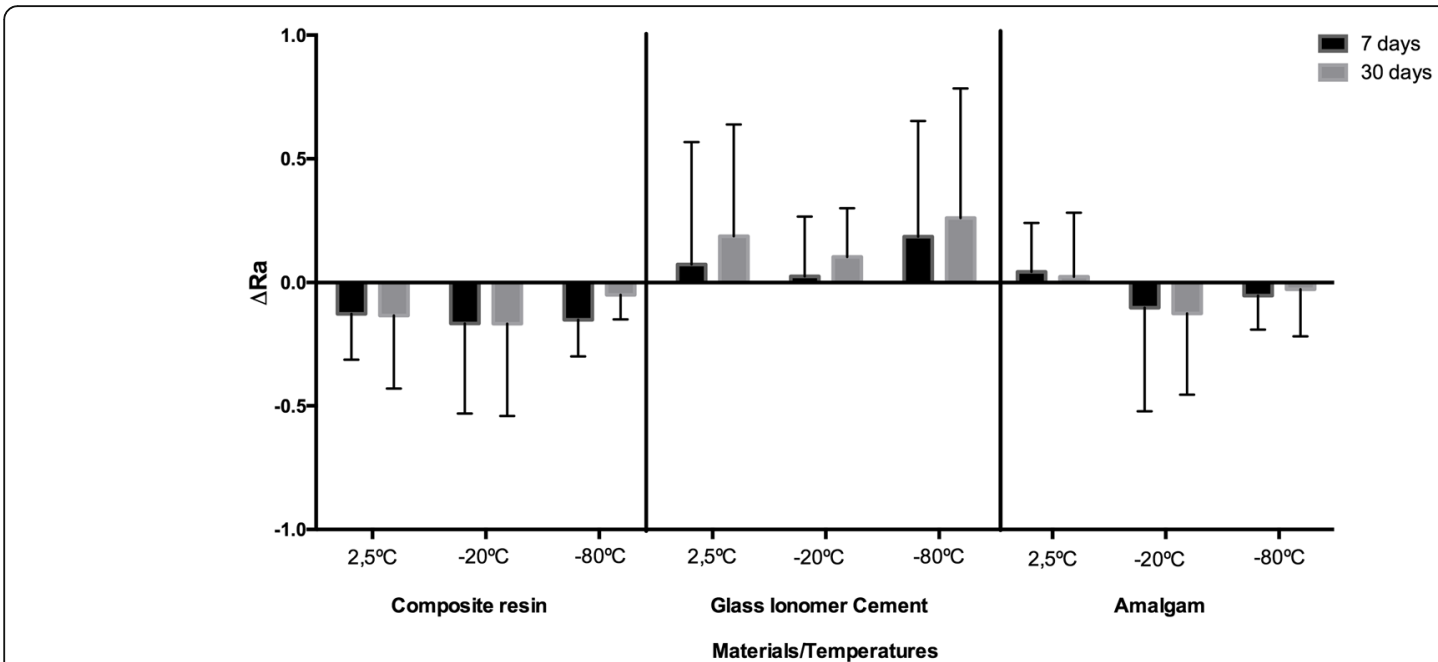

Fig. 1 Graphic representation of the comparison of $\triangle \mathrm{Ra}$ of the materials when exposed to the cold temperatures (two-way ANOVA, repeated measures, Bonferroni test, $p<.05)$. For all comparisons, $p>.05$

dental restorative materials present in the teeth of victims of freezing or carbonization. The authors started from the null hypothesis that there would be no difference in the properties studied in each material, irrespective of low or high temperatures and periods to which they were subjected. The results demonstrated that the hypothesis tested could be partially accepted, because the heat promoted significant changes $(p<.05)$ in the surface roughness of GIC and amalgam, and in the microhardness of GIC; however, the action of the cold caused no significant change $(p>.05)$ in the properties of any of the restorative materials studied.

For the exposure to the cold, the temperatures of 2.5 ${ }^{\circ} \mathrm{C},-20^{\circ} \mathrm{C}$, and $-80^{\circ} \mathrm{C}$ were selected, due to the possibility of precisely maintaining these temperatures using refrigerators. The 7- and 30-day periods correspond to the short and the longer time intervals that bodies can be found under conditions of extreme cold.

The analyses of the changes in the surface roughness and microhardness, in different periods, could contribute to estimating the period between death and the

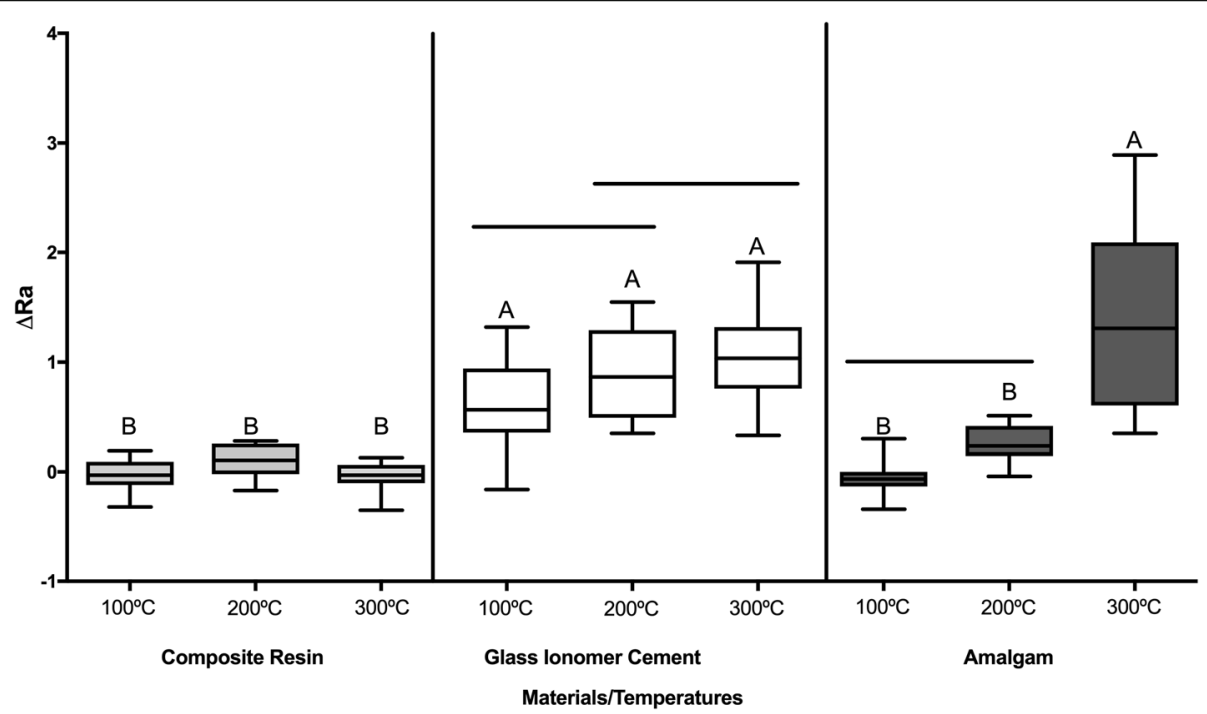

Fig. 2 Graphic representation of the comparison of $\Delta$ Ra between the materials when exposed to the heat action (one-way ANOVA, Tukey test, $p$ $<.05)$. For all the comparisons between the sample groups of $C R, p>.05$. For $\mathrm{GlC}$ and amalgam, the horizontal lines over the bars indicate no statistically significant difference $(p>$.05). Different letters indicate significant difference $(p<.05)$ between the materials at the same temperature. $\mathrm{CR}=$ composite resin. $\mathrm{GlC}=$ glass ionomer cement 


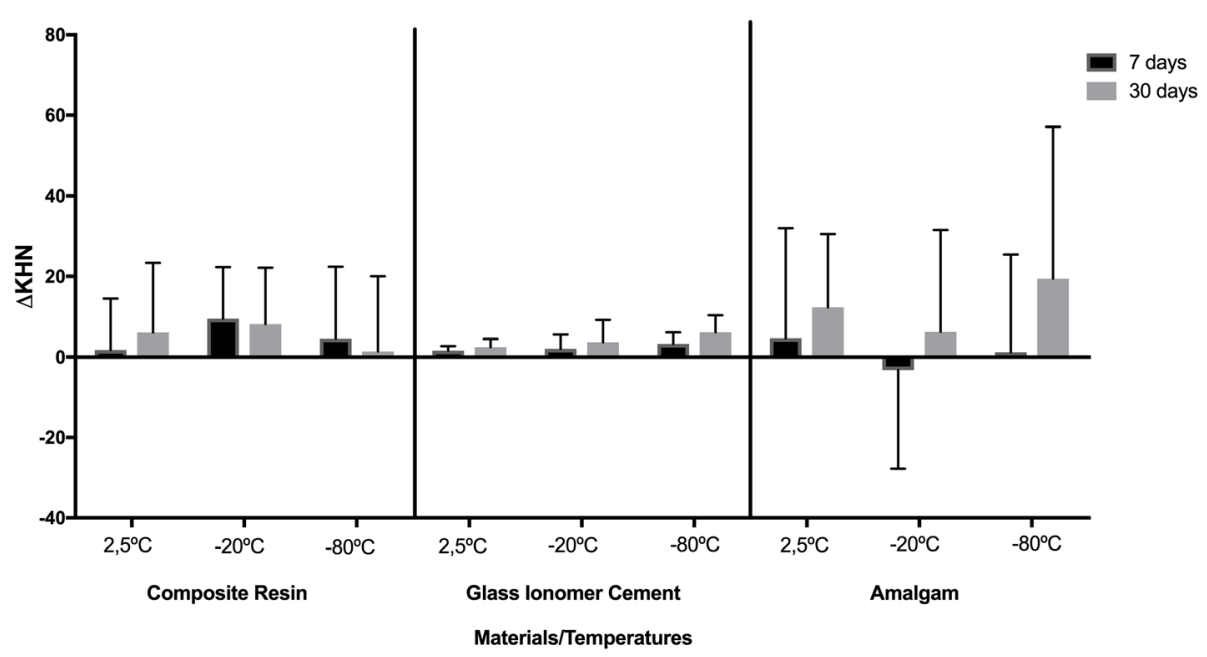

Fig. 3 Graphic representation of the comparison of $\triangle K H N$ between the materials when exposed to the cold temperatures (two-way ANOVA, repeated measures, Bonferroni test, $p<.05)$. For all comparisons, $p>.05$

necroscopic exam of the victim's mouth. The elucidation of the time of death may be essential for establishing the medical and legal causa mortis (Huntington et al. 2007) and also to present evidence of whether the corpse suffered antemortem or post-mortem lesions or displacements, thus contributing to the experts' investigations.

Estimating the time of death by the analysis of the cooling and rigidity of the corpse and the emergence of hypostatic stains is not possible in cases of late occurrence of the corpses (Levy et al. 2010). However, the presence of dental remnants may confirm the analysis of the roughness and hardness of the restorative material as a practical and accessible chronological thanatology technique and not only as an auxiliary identification method.

For the exposure to the heat, a pilot study indicated to establish, as analysis parameters, the temperatures of $100^{\circ}$ C, $200{ }^{\circ} \mathrm{C}$, and $300{ }^{\circ} \mathrm{C}$, because up to $300^{\circ} \mathrm{C}$ the three materials selected could still have the changes in surface roughness and microhardness analyzed. Above this temperature, there was catastrophic damage to the structure of the materials.

For the temperature to reach $300^{\circ} \mathrm{C}$ inside the mouth, it would be necessary for the fires to provide ambient

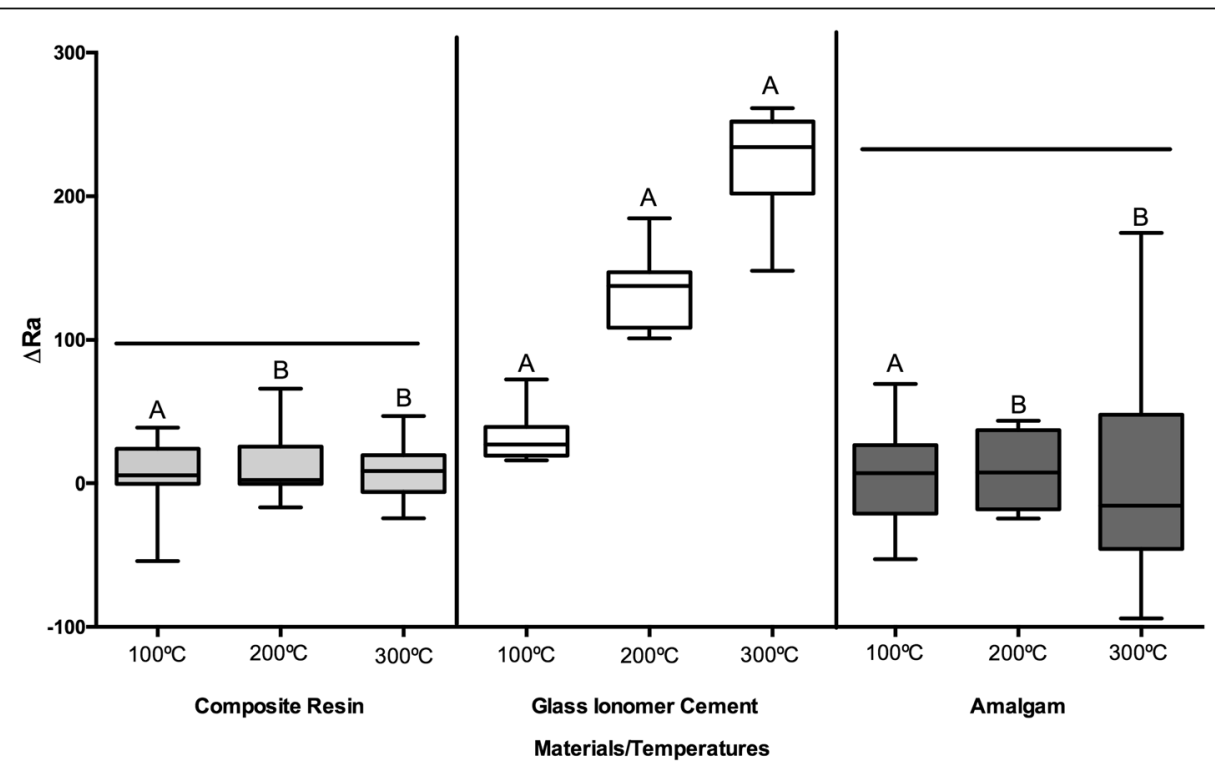

Fig. 4 Graphic representation of the comparison of $\triangle K H N$ between the materials when exposed to the heat action (one-way ANOVA, Tukey test, $p<.05)$. The horizontal lines over the bars indicate no statistically significant difference $(p>.05)$. Different letters indicate significant difference $(p$ $<.05)$ between the materials at the same temperature 
temperatures around $800^{\circ} \mathrm{C}$ to $1000^{\circ} \mathrm{C}$ for extended periods, such as $60 \mathrm{~min}$ or longer (Marella et al. 2012). For this study, the period of $15 \mathrm{~min}$ was selected for the exposure to the heat, following a previously described methodology (Patidar et al. 2010; Pol et al. 2015), in which the authors concluded that the changes that occurred in the materials after $60 \mathrm{~min}$ were no different from those that occurred after they were exposed to the heat for $15 \mathrm{~min}$.

Bovine teeth were selected as the substrate for performing the cavity preparations and the restorative procedures because they are more easily obtainable than human teeth. Moreover, when in non-carious conditions, they do not generate any harm to the tests proposed, since the aim of this study was to evaluate the changes that occurred in the materials and not specifically in the dental structures.

Bovine teeth make it easier to standardize the samples, with a lower risk of infection, besides the bioethical issues (Wang et al. 2012; Zhang et al. 2013). They present similarities to the human dental tissues, particularly concerning the orientation of the enamel prisms, an equivalent percentage by weight of calcium, and protein matrix composed of the same amino acids (Wang et al. 2012). As regards dentin, there are some controversies relative to the similarity between the teeth of both species. However, there is a consensus in the literature that in shallow cavities, with a depth of $2 \mathrm{~mm}$, bovine dentin has been shown to be feasible for adhesion, providing adequate bond strength when compared with human dentin (Zhang et al. 2013).

The analysis of the surface roughness in the CR restorations possibly found in a post-mortem examination would not confirm whether the victim suffered the action of the heat, in cases in which the report on the external condition of the corpse did not reveal this situation. This is because the heat did not cause sufficient changes $(p>.05)$ in its surface roughness. In GIC restorations, high surface roughness suggests exposure of the body to the heat. The dryness of GIC due to evaporation and consequent loss of water (syneresis), exposing its filler particles and leading to the appearance of small cracks, indicates that the temperature of exposure was higher than $300^{\circ} \mathrm{C}$.

The surface roughness of $\mathrm{CR}$, on an average, was always lower than that of GIC, corroborating the results of Liberman and Geiger 1994, de Araújo et al. 1998, according to whom GICs are rougher because of the composition of the material itself. Relative to particle size, CRs have smaller inorganic particles, while conventional GICs have larger particles (Gladys et al. 1997). This leads to more significant irregularities in the surface of GIC.

Teeth restored with amalgam, in which the material shows high values of surface roughness, suggest exposure of the victim's mouth to temperatures over $300{ }^{\circ} \mathrm{C}$. At this temperature, the formation of bubbles occurs resulting from evaporation of the mercury present in its composition (Patidar et al. 2010), which generates increases in its surface roughness.

In the cold tests, the low temperatures, up to $-80^{\circ} \mathrm{C}$, did not structurally modify any of the materials to the point of changing their roughness. Thus, analyzing the surface roughness by itself, it is not possible to affirm whether or not the materials suffer the action of cold, or to which temperature they were subjected, up to $-80^{\circ} \mathrm{C}$, even if they were exposed for prolonged periods of up to 30 days.

However, discrimination could be made between CR and GIC using the surface roughness analysis, because they follow different patterns, irrespective of the action of the cold or heat. As the exposure temperature increased up to $300^{\circ} \mathrm{C}$, the heat only made the distinction more evident due to the changes that occurred in GIC.

Analysis of the microhardness of a restorative material is commonly related to its mechanical strength and degree of conversion. The advantage of the study of the Knoop microhardness is the possibility of finding a correlation between the hardness of different materials (Ferracane 1985), since amalgam, differently from CR and GIC, is considered a friable material. It does not only deform when subjected to stress but it also fractures (Willems et al. 1993).

When exposed to the heat, the CR did not undergo significant changes $(p>.05)$ in its Knoop microhardness. So, it is not possible to define whether the $\mathrm{CR}$ was exposed to the heat, or to which temperature it was subjected, up to $300^{\circ} \mathrm{C}$, analyzing this property by itself; these results are similar to those found by Basting et al. 2002. However, the heat could lead to the degradation of $\mathrm{CR}$ due to combustion and volatilization of the organic components with consequent loss of mass (Dionysopoulos and Watts 1989).

The loss, in mass, of the organic matrix and the resultant increase in the inorganic portion due to this loss may lead to increase in microhardness (Dionysopoulos and Watts 1989). The heat would also be an additional polymerization factor, which would increase the degree of conversion of the $\mathrm{CR}$, providing the matrix with a more homogeneous and resistant structure, improving its mechanical properties (Loza-Herrero et al. 1998), including microhardness.

In GIC, a significant increase $(p<.05)$ in its microhardness was verified, and this was more intense the higher the exposure temperature, up to $300^{\circ} \mathrm{C}$. At $100^{\circ}$ $\mathrm{C}$, the microhardness increased by approximately five times, compared with the mean value before the action of the heat. At $200{ }^{\circ} \mathrm{C}$, the elevation was even more significant, attaining an increase of around 20 times the 
value of the initial mean. When the materials were exposed to $300^{\circ} \mathrm{C}$, the rate of increase in microhardness was maintained at a very high level and was a little higher compared with the increase at $200^{\circ} \mathrm{C}$.

It is possible to distinguish the tooth-colored materials based on the elevation of the microhardness of GIC by itself, at $200^{\circ} \mathrm{C}$ and $300^{\circ} \mathrm{C}$. The action of the heat leads to a loss of water and reduction in the matrix of GIC, which causes a proportional increase in the percentage of filler particles. Studies (Okada et al. 2001; CattaniLorente 1994) have observed an increase in some mechanical properties, such as the hardness, of the GIC due to drying of this material.

Some authors (Okada et al. 2001; Cattani-Lorente 1994; Mojon et al. 1996) have affirmed that an increase in the microhardness values of the GICs usually occurs with the passage of time. This increase is probably related to the acid-base reaction that occurs in a more slowly and continuously way, in which protons attack and degrade the structure of the aluminosilicate glass, releasing calcium, strontium and aluminum ions that react with the carboxylic groups (Xie et al. 2000).

However, in the tests conducted at low temperatures in this study, even after 30 days of exposure, no significant change $(p>.05)$ in the microhardness occurred in any of the materials studied, including GIC. Perhaps 30 days period has been too short for these changes to occur, or the action of the cold may have retarded the acid-base reaction of GIC. In spite of this, the discrimination between the tooth-colored materials can be made by the analysis of this property by itself, because the hardness pattern of the $\mathrm{CR}$ is quite distinguished from that one of the GIC, a fact that may be related to the type and quantity of inorganic particles by volume in its composition.

Concerning the amalgam, as there was no significant change $(p>.05)$ in its microhardness due to the heat, it is not possible to determine whether amalgam was exposed to the heat or to which temperature, up to $300^{\circ} \mathrm{C}$, by the analysis of this property by itself. Researchers (Willems et al. 1993; Patsurakos and Moberg 1990) have reported that the microhardness of the amalgam is a time-dependent property, probably due to the lower content of mercury, that evaporates over the course of time, and also to the more significant quantity of crystallization reactions, that leads to more $\gamma$ phases than $\gamma 1$ and $\gamma 2$ phases; these latter two present lower hardness values than the phase $\gamma$ (Patsurakos and Moberg 1998).

However, in the tests conducted at low temperatures in this study, even after 30 days of exposure, no relevant change occurred in the microhardness of the amalgam. Perhaps the 30 days period has been insufficient for the occurrence of these changes. However, as this study is related to forensic purposes, such period could be considered extensive concerning the permanence or the find of a human body or bones in environmental conditions of extreme cold.

In the microhardness analysis, high standard deviation was verified in the readouts of the three materials evaluated, both in the heat and cold tests. For the tooth-colored materials, this may have occurred because there is the possibility of the penetrator of the microhardness tester to hit the harder filler particles or even the matrix, at the moment in which it presses against the material, leading to a significant difference in the microhardness values for the same restoration. In the heat tests, another limiting factor relative to the GIC and adverse for the microhardness evaluation was the appearance of microcracks in the restoration that occurred after heating to $300^{\circ} \mathrm{C}$. When putting pressure on the restoration surface, the penetrator may make the mark precisely on one of these cracks, or in their proximities, and cause small movement of a portion of the restoration, which would undoubtedly influence the microhardness evaluation.

Concerning the amalgam, the same could occur with the crystals of phase $\gamma 1$ and phase $\gamma 2$, being the first more resistant than the latter. Thus, the penetrator tip can hit one phase or the other, leading to a significant standard deviation.

\section{Conclusion}

The authors concluded that the heat caused no change in the surface roughness and microhardness of the CR. In GIC, the surface roughness and the microhardness increased as the temperature increases up to $300^{\circ} \mathrm{C}$. The amalgam exposed to the heat underwent no change in its microhardness. As regards the surface roughness, significant changes occurred at $300^{\circ} \mathrm{C}$.

The cold temperatures did not produce changes in the surface roughness or microhardness of the three restorative dental materials selected. Therefore, the analysis of these properties is not useful to be used as a chronological thanatology technique, because it is not possible to specify the period during which the materials were subjected to the action of the cold.

The surface roughness and Knoop microhardness tests may be of help to Forensic Odontology in human identification procedures because they are capable of distinguishing tooth-colored restorative materials, irrespective of the action of the heat or cold.

\section{Abbreviations}

CR: Composite resin; GIC: Glass ionomer cement; KHN: Knoop hardness number; Ra: Roughness average; $\Delta K H N$ : Changes in the Knoop microhardness; $\triangle$ Ra: Changes in the surface roughness

Acknowledgements Not applicable 
Availability of data and material

Not applicable

\section{Funding}

Not applicable

\section{Authors' contributions}

$\mathrm{RCB}$ was responsible for the collection and preparation of the samples, execution of laboratory experiments, the wording of the manuscript and translation, and contributed to the idea. SAFV was responsible for the collection and preparation of the samples, execution of laboratory experiments and translation, and contributed to the idea. RHAS contributed to the study planning and its translation. FCPPS was responsible for the design and planning of the study, the idea, statistical analysis and interpretation of the data, translation, and supervision. All persons listed as authors have contributed to preparing the manuscript and no person or persons other than the authors listed have contributed significantly to its preparation. All authors read and approved the final manuscript.

\section{Ethics approval and consent to participate}

Not applicable

\section{Consent for publication}

All authors give their consent for publication.

\section{Competing interests}

The authors declare that they have no competing interests.

\section{Publisher's Note}

Springer Nature remains neutral with regard to jurisdictional claims in published maps and institutional affiliations.

\section{Author details}

'Department of Stomatology, Public Oral Health, and Forensic Dentistry, Ribeirao Preto School of Dentistry, University of Sao Paulo, Ribeirao Preto, Sao Paulo, Brazil. ${ }^{2}$ Department of Dental Materials and Prosthodontics, Ribeirao Preto School of Dentistry, University of Sao Paulo, Av. do Café, s/n 14040-904, Ribeirao Preto, Sao Paulo, Brazil.

Received: 5 December 2018 Accepted: 12 February 2019

Published online: 23 February 2019

\section{References}

Basting RT, Serra MC, Rodrigues AL Jr (2002) In situ microhardness evaluation of glass-ionomer/composite resin hybrid materials at different post-irradiation times. J Oral Rehabil 29(12):1187-1195. https://doi.org/10.1046/j.1365-2842. 2002.00906.x

Biancalana RC, Vicente SAF, Pires-de-Souza FCP, Silva RHA (2017a) Color stability of dental restorative materials submitted to heat sources, for forensic purposes. J Forensic Sci 62(2):355-360. https://doi.org/10.1111/1556-4029. 13292

Biancalana RC, Vincenti SAF, Pires-de-Souza FCP, Silva RHA (2017b) Color stability of dental restorative materials submitted to cold temperatures for forensic purposes. J Forensic Legal Med 51:63-68. https://doi.org/10.1016/j.jflm.2017. 07.016

Blau S, Briggs CA (2011) The role of forensic anthropology in disaster victim identification (DVI). Forensic Sci Int 205(1-3):29-35. https://doi.org/10.1016/j. forsciint.2010.07.038

Boyd J, Haegeli P, Abu-Laban RB, Shuster M, Butt JC (2009) Patterns of death among avalanche fatalities: a 21-year review. Can Med Assoc J 180(5):507512. https://doi.org/10.1503/cmaj.081327

Bush MA, Bush PJ, Miller RG (2006) Detection and classification of composite resins in incinerated teeth for forensic purposes. J Forensic Sci 51(3):636-642. https://doi.org/10.1111/j.1556-4029.2006.00121.x

Cattani-Lorente MA, Godin C, Meyer JM (1994) Mechanical behavior of glass ionomer cements affected by long-term storage in water. Dent Mater 10(1): 37-44. https://doi.org/10.1016/0109-5641(94)90020-5

de Araújo MAM, Araújo RM, Marsilio AL (1998) A retrospective look at esthetic resin composite and glass-ionomer class III restorations: a 2-year clinical evaluation. Quintessence Int 29(2):87-93 http://www.quintpub.com/journals/ qi/abstract.php?article_id=5433\#.XGqvSZNKiX2. PMID: 9643241
Della Bona A, Barrett AA, Rosa V, Pinzetta C (2009) Visual and instrumental agreement in dental shade selection: three distinct observer populations and shade matching protocols. Dent Mater 25(2):276-281. https://doi.org/10. 1016/j.dental.2008.09.006

Dionysopoulos P, Watts DC (1989) Dynamic mechanical properties of an inlay composite. J Dent 17(3):140-144. https://doi.org/10.1016/03005712(89)90110-3

Fereira JL, de Fereira AE, Ortega Al (2008) Methods for the analysis of hard dental tissues exposed to high temperatures. Forensic Sci Int 178(2-3):119-124. https://doi.org/10.1016/j.forsciint.2007.12.009

Ferracane JL (1985) Correlation between hardness and degree of conversion during the setting reaction of unfilled dental restorative resins. Den Mater 1(1):11-14. https://doi.org/10.1016/50109-5641(85)80058-0

Gladys S, Van Meerbeek B, Braem M, Lambrechts P, Vanherle G (1997) Comparative physico-mechanical characterization of new hybrid restorative materials with conventional glass-ionomer and resin composite restorative materials. J Dent Res 76(4):883-894. https://doi.org/10.1177/ 00220345970760041001

Hill AJ, Lain R, Hewson I (2011) Preservation of dental evidence following exposure to high temperatures. Forensic Sci Int 205(1-3):40-43. https://doi. org/10.1016/j.forsciint.2010.08.011

Huntington TE, Higley LG, Baxendale FP (2007) Maggot development during morgue storage and its effect on estimating the post-mortem interval. J Forensic Sci 52(2):453-458. https://doi.org/10.1111/j.1556-4029.2007.00385.x

Leitão J, Hegdahl T (1981) On the measuring of roughness. Acta Odontol Scand 39(6):379-384. https://doi.org/10.3109/00016358109162710

Levy AD, Harcke HT, Mallak CT (2010) Postmortem imaging: MDCT features of postmortem change and decomposition. Am J Forensic Med Pathol 31(1): 12-17. https://doi.org/10.1097/PAF.0b013e3181c65e1a

Liberman R, Geiger S (1994) Surface texture evaluation of glass ionomer restorative materials polished utilizing poly (acrylic acid) gel. J Oral Rehabil 21(1):87-94. https://doi.org/10.1111/j.1365-2842.1994.tb01127.x

Loza-Herrero MA, Rueggeberg EA, Caughman WE, Schuster GS, Lefebvre CA, Gardner EM (1998) Effect of heating delay on conversion and strength of a post-cured resin composite. J Dent Res 77(2):426-431. https://doi.org/10. 1177/00220345980770021201

Marella GL, Perfetti E, Arcudi G (2012) Differential diagnosis between cranial fractures of traumatic origin and explosion fractures in burned cadavers. J Forensic Legal Med 19(3):175-178. https://doi.org/10.1016/j.jflm.2011.12.004

Michaud CL, Foran DR (2011) Simplified field preservation of tissues for subsequent DNA analyses. J Forensic Sci 56(4):846-852. https://doi.org/10. 1111/j.1556-4029.2011.01771.x

Mojon P, Kaltio R, Feduik D, Hawbolt EB, MacEntee MI (1996) Short-term contamination of luting cements by water and saliva. Dent Mater 12(2):8387. https://doi.org/10.1016/S0109-5641(96)80073-X

Okada K, Tosaki S, Hirota K, Hume WR (2001) Surface hardness change of restorative filling materials stored in saliva. Dent Mater 17(1):34-39. https:// doi.org/10.1016/S0109-5641(00)00053-1

Patidar KA, Parwani R, Wanjari S (2010) Effects of high temperature on different restorations in forensic identification: dental samples and mandible. J Forensic Dent Sci 2(1):37-43. https://doi.org/10.4103/0974-2948.71056

Patsurakos A, Moberg LE (1990) Marginal microhardness of corroded amalgams: a comparative in vitro study. Eur J Oral Sci 98(4):326-335. https://doi.org/10 1111/j.1600-0722.1990.tb00980.x

Patsurakos A, Moberg LE (1998) Corrosion behavior and microhardness of three amalgams. Eur J Oral Sci 96(4):376-383. https://doi.org/10.1111/j.1600-0722. 1988.tb01570.x.

Pol CA, Ghige SK, Gosavi SR, Hazarey VK (2015) Effects of elevated temperatures on different restorative materials: an aid to forensic identification processes. J Forensic Dent Sci 7(2):148-152. https://doi.org/10.4103/09751475.154591

Skinner M, Sterenberg J (2005) Turf wars: authority and responsibility for the investigation of mass graves. Forensic Sci Int 151(2-3):221-232. https://doi. org/10.1016/j.forsciint.2004.12.034

Upadhyay D, Panchal MA, Dubey RS, Srivastava VK (2006) Corrosion of alloys used in dentistry: a review. Mater Sci Eng A 432(1-2):1-11. https://doi.org/10.1016/ j.msea.2006.05.003

Valenzuela A, Martin-De Las Heras S, Marques T, Marques T, Exposito N, Bohoyo JM (2000) The application of dental methods of identification to human burn victims in a mass disaster. Int J Legal Med 113(4):236-239. https://doi.org/10. 1007/s004149900099 
Wang C, Li Y, Wang X, Zhang L, Tiantang FB (2012) The enamel microstructures of bovine mandibular incisors. Anat Rec Adv Integr Anat Evol Biol 295(10): 1698-1706. https://doi.org/10.1002/ar.22543.

Willems G, Celis JP, Lambrechts P, Braem M, Vanherle G (1993) Hardness and Young's modulus determined by nanoindentation technique of filler particles of dental restorative materials compared with human enamel. J Biomed Mater Res 27(6):747-755. https://doi.org/10.1002/jbm.820270607

Xie D, Brantley WA, Culbertson BM, Wang G (2000) Mechanical properties and microstructures of glass-ionomer cements. Dent Mater 16(2):129-138. https:// doi.org/10.1016/S0109-5641(99)00093-7

Zhang L, Tang T, Zhang ZL, Liang B, Wang XM, Fu BP (2013) Improvement of enamel bond strengths for conventional and resin-modified glass ionomers: acid-etching vs. conditioning. J Zhejiang Univ Sci B 14(11):1013-1024. https:// doi.org/10.1631/jzus.B1300034

\section{Submit your manuscript to a SpringerOpen ${ }^{\circ}$ journal and benefit from:}

- Convenient online submission

- Rigorous peer review

- Open access: articles freely available online

- High visibility within the field

- Retaining the copyright to your article

Submit your next manuscript at $\boldsymbol{\nabla}$ springeropen.com 